\title{
Krasnoyarsk in 1917 - the Middle of 1918 as Viewed by the Newspaper Krasnoyarskii Rabochii
}

\author{
Elena A. Romanova* \\ Krasnoyarsk State Institute of Arts \\ 22 Lenin Str., Krasnoyarsk, 660049, Russia
}

Received 19.01.2017, received in revised form 07.08.2017, accepted 12.08.2017

The life of Krasnoyarsk during the period of the end of World War I, the beginning of the Civil War and the revolutionary events of 1917 is studied in the article. Political, socio-economic and cultural work against the background of modern information wars and cultural values is under consideration.

Keywords: information wars, cultural values, World War I, Civil war, solution of political, socioeconomic and cultural problems in Krasnoyarsk.

DOI: 10.17516/1997-1370-0131.

Research area: historical sciences and archeology, philology.

Modern information wars are actively fighting for the minds, values and life attitudes of people. Our ideological opponents are trying to accomplish decoding of spiritual foundations, propagandize violence, devaluate the concepts of "good", "morality" and "justice", as well as discredit family values, destroy traditional identity and replace it with unlimited freedom, which leads to moral degradation (Zapesotskii, 2015). The subject of their study was the history of the $20^{\text {th }}$ century, which was distorted in such a way that failures, defeats and moral lapses were supposed to become the object of pride. The study of the history of Krasnoyarsk in the turning period of 1917-1918 (Romanova, 2014; Tsareva, 2014) allows answering the question about the state of traditional identity, the values of a civil, social and moral culture and the probability of forming a "catastrophic" type of consciousness.

The Ukrainian question occupied a big place in the ideological work of the provincial and city authorities in Krasnoyarsk, which was carried out with the help of the press. In the Krasnoyarskii Rabochii they wrote: "Why Lutsk is Ukraine? And after all, mostly Poles and Jews lived there, and there were Germans, Czechs and Poles in the districts"; "Local residents in Lutsk had troubles in understanding ads in the Ukrainian language"; "Why Nikolayev and Odessa are Ukrainian, although they saw nothing Ukrainian"; "The language of commissars, commandants and officials is a mixture of Russian and Belarusian"; "The intelligentsia and peasants cannot understand why Kharkiv and Bryansk should be in different states". Here, in the first

(C) Siberian Federal University. All rights reserved

* Corresponding author E-mail address: afinaadr@mail.ru 
place, such a value as "justice" was formed. It is especially relevant in the period of wars and revolutions, when values are reassessed, because for the people who are limited in their rights this is the most important means of struggle for their freedom. On the one hand, wartime toughens social mores, and on the other hand, the presence of the value of "justice" in society makes it more humane.

In middle of May 1918 a receiving radio station (wireless telegraph) was installed in Krasnoyarsk. There was a connection with Moscow. On May 14 the first radiogram was received. Thus, the city was becoming more modern, and the governing of Krasnoyarsk from the center mobile.

The end of World War I influenced the political life of Krasnoyarsk. Re-elections of the Soviets were held in the city in connection with the old army disbandment. The goal was to protect this government body from "traitors". The ideological component was predominating in the policy of power in the revolutionary period.

After the end of the First World War, the evacuated workers and engineer building brigades returned from the front. They were paid off in accordance with the obligations issued by front organizations, which must have been confirmed by the Main Evacuation Agency and Zemgor (Zemsky Union, the Union of Towns). The remuneration for the soldiers and officers after mobilization from the army was different: for those who had a family - a two-month salary, for a single person - a third of the salary they received during military service. This was in accordance with the people's ideas of justice.

The civil war also exerted its influence on the life of the country and Krasnoyarsk. Under the CEC decree of April 22, 1918, citizens who voluntarily joined the Red Army were obliged to serve in it for at least six months. In case of escape from the army to the term, the punishment could be deprivation of the rights of citizens of the Soviet republics. In Krasnoyarsk, at that time, a detachment of Latvian communists, which was placed under the orders of the commander of troops Markovsky, was formed. Against the background of democratic euphoria, "strict discipline in the army", which prevented every protest and depersonalized a person was criticized in the "Krasnoyarskii Rabochii". This clearly was not combined with military tasks, but political punishment was foreseen for escaping the army.

In April 1918 at the CEC session the task to transfer from the army on a voluntary basis to the army with compulsory military service was set. For this, a new apparatus for the armed forces registration was needed. It should have consisted of volost, uyezd and provincial commissariats, each of which included a leader and two commissars. A month after the CEC decision in Krasnoyarsk, it was decided to convene a provincial congress of military departments with the aim of organizing a provincial military department and a district committee for the supply and support of the Red Army. This required strengthening the formation of values of civil and social culture of "patriotism" and "responsibility".

Among the power structures in the wartime, the soldiers' section of the Krasnoyarsk Soviet of Workers', Soldiers' and Peasants' Deputies actively worked. In 1917 it advocated the compilation of voter lists - servicemen to the Constituent Assembly. The Soldier's Section was also engaged in ensuring the replacement of ankle boots as unsuitable military footwear with high boots and exercising control over the meal station. Another line of activity was formation of the third company and the approval of I.P. Litovchenko as its commander. The liquidation of the regiments was completed and representatives of the $15^{\text {th }}$ regiment were left to verify the instructions of the liquidation commission. The soldiers' section 
of the Krasnoyarsk Soviet of Workers', Soldiers' and Peasants' Deputies, apart from military problems, were engaged in the lists of voters servicemen to the Constituent Assembly, which indicated the formation of such a value of social culture as "democratism".

A major role in establishing order in Krasnoyarsk was played by the Revolutionary Tribunal, a symbol of revolutionary and wartime. The presidents of the tribunal were Osinkin and Korolev. The members of the Revolutionary Tribunal were represented by the Central Bureau of Trade Unions and following railway workers: Mensky, Zalevsky, Shipel, Bagaev, Denisov, Guralin, Kruglikov, Cherepanov and Vyshkovsky. Pavlovsky was the magistrate and Jurgens - the solicitor of revolutionary law. Deserters were punished up to and including deprivation of the rights of citizens of the Soviet Republic. For bad behavior they were expelled from the Red Guard for one year. Witnesses who failed to appear in the Revolutionary Tribunal without a good reason were fined from 20 to 100 rubles. Punishment for the transportation of alcohol was a fine of 500 rubles or a replacement for 14 days. An actor of the "First Circus Cooperative" R. Pelarzh according to the verdict of the tribunal was punished for the fraud with tickets by the sentence of six months in the Krasnoyarsk provincial prison; and I. Shapiro - for illegal searches on false credentials. The revolutionary tribunal formed such values as "responsibility" and "discipline" among the residents of Krasnoyarsk.

Those who were sentenced to prison stayed in the detention center. In June 1918 there were 400 citizens on criminal cases, 20 as counterrevolutionaries, and 12 White Guards. During the day the prisoners were fed with 1 pound of bread and 2 zolotniks of sugar. Visits were allowed twice a week. Thus, in this respect, human rights were observed. On the other hand, under the conditions of revolutionary and wartime, punishment was exercised not only for criminal offenses, but also in accordance with the class principle.

Political rallies dedicated to May 1 played an important ideological role in Krasnoyarsk. They were held until 3:00 pm. In 1918 there were following inscriptions on the banners: "The Power of the Soviets - the Power of Labor", "Coming Socialism", "The $3^{\text {rd }}$ International". They were attended by about 10,000 people and three orchestras. Three cars were used as a stand for speakers. At the rally A. Perenson, A. Schneider and N. Kopylov spoke on the topic of "Soviet power", Ya. Bograd, V. Yakovlev and D. Kuznetsov on the " $3^{\text {rd }}$ International", G. Veinbaum, A. Pomerantseva and Shingarevsky on "Future Socialism" and "Fundamentals of Marxism". Pattaki, Klemanchich and Kolgof spoke from the prisoners of war. The Mensheviks with the slogan "Constituent Assembly" were not allowed to join, its time had passed. Holiday ideological education encompassed not only the residents of Krasnoyarsk, but prisoners of war as well.

The press was also used to strengthen the Social Democrats Internationalists influence on the prisoners of war. On 7 April 1918 the first issue of the newspaper "Vorwärts" in German and "Elore" in Hungarian, which in both cases meant "Forward", were printed. They published appeals and calls for unity, overviews of the Russian revolution, telegrams and announcements.

On February 23, 1918 the Council of POWs of German, Hungarian and Austrian Soldiers' Deputies was established. On May 15, the Tomsk international detachment of prisoners of war went through Krasnoyarsk to the east to fight Ataman Semyonov. During the stop, his revolutionaryminded representatives sent a delegation to the military camp to the Krasnoyarsk prisoners of war and there, after seeing the portrait of Kaiser Wilhelm, pierced it. The ideological cooperation 
of the Siberian detachments of the prisoners of war was established and the value of the communicative culture of "brotherhood" was formed.

Lectures were a great financial source for ideological work. Ya. Bograd, a member of the Central Siberian Regional Bureau, reported in May 1918 for conducting lectures during the year. 1519 rubles 35 kopecks were received. Of them, 564 rubles 40 kopecks were received for lectures on "International and European War", which were delivered in Krasnoyarsk. The money was transferred to different needs of ideological work.

A significant educational role in Krasnoyarsk was played by the Peasants' Hall of People (Fig. 1). The lectures on "Alcoholism and Degeneration", "On Russian History" and others were delivered there. They were accompanied by the performances of actors with poetic works, musical programmes and stage productions. The production of A.N. Ostrovsky "Stay in Your Own Sled" was among the latter. There were also musical and vocal evenings with a concert part (played by the POW orchestra and the amateur Great Russian Orchestra) and dances. The price for the tickets ranged from 50 kopecks to 1 ruble 50 kopecks. Judging by the price policy, the people with low income were also got education.

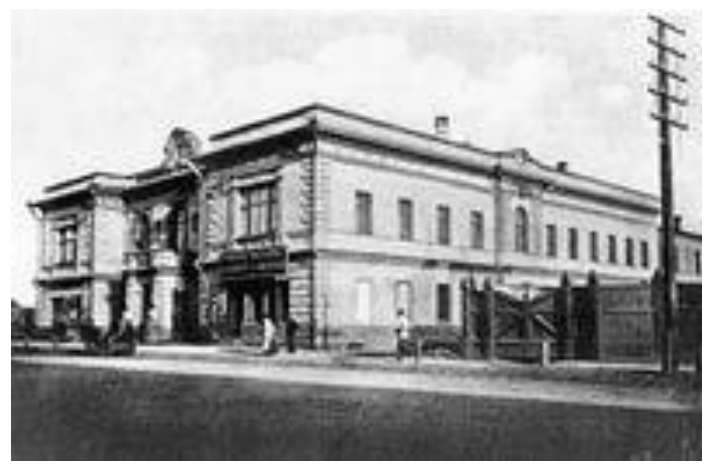

Fig. 1. Hall of People - Krasnoyarsk Pushkin Drama Theatre
There was a clear schedule for the work of the Hall of People. From 12 to 3 pm children could study music, singing, reciting and listen to stories. From 4 to $7 \mathrm{pm}$ there was culturaleducational and general educational work for adults, and at $9 \mathrm{pm}$ - musical evenings and amateur performances. The formation of such values of intellectual culture as "cognition" and "creativity", taking into account the time convenient for children, was taking place there.

Alibrary of 11.000 books with 5 encyclopedias among them was created in the Hall of People. It was made up of the liquidated libraries of the $15^{\text {th }}$ Regiment, the Eparchial Brotherhood, the Excise Office and the Krasnoyarsk Wine Storage. The Council of the National Economy financed "Reference Literature". It should have consisted of a revolutionary calendar, the structure of the power organization (national, provincial, uyezd and volost), staff of the provincial and district Soviets, statistics on the Yenisei province and a reference department. The centralized library in the Hall of People was large, and the reference literature in it could have an ideological component.

The estimate for the maintenance of the Workers' and Peasants' Hall of People included the cost of a weekly newspaper (24,000 rubles), the purchase of books, newspapers and magazines subscription (16,000 rubles), the purchase of tools for clubs (16,000 rubles), science tours $(10,000$ rubles), organizing exhibitions (100,000 rubles) and bonuses for inventions (12,000 rubles) (Krasnoyarskii rabochii, 1918, 29 maia). Despite the difficulties of the military and revolutionary times the estimate was of educational and developing nature and suggested stimulation of creativity.

The City Public Library also functioned In Krasnoyarsk. The new journals included "Prosveshchenie" with Lenin's article "Can the Bolsheviks Retain State Power?" and Glebov's 
"War and National Economy"; "Professional'nyi Vestnik" with the article "Worker Control"; "Freedom-Based Education" and "Free School" with Ventsel's article "Proclamation of the Declaration of the Rights of the Child". On the one hand, new journals were subscribed to in accordance with ideological guidelines, and on the other hand, taking into account the democratic values of the rights of the child.

Artistic life activization and rapid development of the musical culture of Krasnoyarsk in the late $19^{\text {th }}$ - early $20^{\text {th }}$ centuries were accompanied by the establishment of clubs (meetings) and amateur societies. They became the centers of artistic life. Music and drama sections and string and brass bands were created within the clubs, initial musical training was provided.

In the early $20^{\text {th }}$ century two clubs were established in the city: one of them within the Volonteer Fire Society and another within the Railway Club. The latter later became a club named after Karl Liebknecht, it had orchestral and choir groups, provided initial musical and theatrical education (Fig. 2). It was affectionately nicknamed "Karlusha". In 19171918 the club building was used as a hospital, and later it became a kind of proletarian club of the Krasnoyarsk organization of the RSDLP,

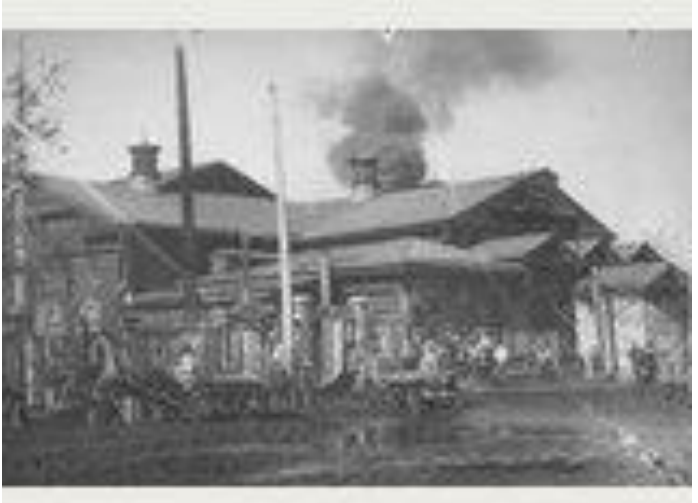

Fig. 2. "Karlusha" - Railway Club in Krasnoyarsk where they had evening meetings, performances, debates, rallies of the city workers and meetings of the Krasnoyarsk organization of the RSDLP.

The opening of the club "K. Marx House" on Sovetskaya Street in the premises of the former club of the $15^{\text {th }}$ regiment in May 1918 was a significant event in the city. A. Shneider and A. Pomerantseva delivered a lecture "On the Significance of K. Marx" there. The tickets cost 1 ruble. Later musical and dancing parties were held in K. Marx Club. Essays on art and poems were read there, a string orchestra and a choir performed with "live pictures" and dances started at the end of the evening. The ticket price for the club members was 50 kopecks, for other visitors - 1.5 rubles. "K. Marx House" earned money for propaganda work and with the help of price policy encouraged Krasnoyarsk citizens to join its ranks.

Not only clubs, but also evening parties were devoted to Marx in Krasnoyarsk. One of them was held on May 16, 1918 in the hall of the Executive Committee. In the first part of the evening the choir and the orchestra of prisoners of war performed "The Internationale", "Varshavianka" and "The Red Banner". N. Kopylov recited the poem "The Call" and Valmen "Ah, Do Not Cry, My Friend". A. Subbotin made a report on the life and work of K. Marx in Russian and Kalgof in German. In the second part the choir and the orchestra of prisoners of war performed "La Marseillaise", "Comrades, Let's Bravely March", "Rage, Tyrants", "German Revolutionary Song" and "The Internationale", Subbotin recited the poems "The Hymn of the Workers" and "In the Harbor", Korensky recited "The Capital" and "In the Ring of Fire". A. Pomerantseva made a report "On the Importance of Marx as a Leader of the International Proletariat", G. Veinbaum "Report on Marx" in Russian and Pattake in Hungarian. The evening party was of exceptional ideological nature and encompassed not only the Russian- 
speaking population, but also those who knew it badly - German and Hungarian prisoners of war.

For the people with low level of income and the unemployed free lectures were held in Krasnoyarsk. The speech by M. Parnevsky "Protection of the Socialist Homeland" from the agitation department of the Krasnoyarsk Soviet of Workers', Soldiers' and Peasants' Deputies is among them. In the local newspaper it was possible to read not only announcements of speeches by the well-known political figures, but a detailed content of their lectures as well (Ya. Bograd "Who is Lenin and Why Is He Bullied by the Bourgeois Parties?"). The image of the city with a revolutionary ideological content was formed in Krasnoyarsk.

Lectures could also be sold as separate brochures. The "Krasnoyarskii Rabochii" (Fig. 3) gave propaganda information about their sale. K. Marx's brochure "The Civil War" was sold for 75 kopecks, D. Bedny's fable "Strike the Iron While It Is Hot" with drawings for 60 kopecks, "The Collapse of Capitalism" by A. Mikhailovich for 40 kopecks, "Who Is to Blame for the Defeat at the Front?" by G. Zinoviev and I. Stalin for 40 kopecks; L. Trotsky's "What's Next?" for 30 kopecks and his "When Will the Accursed War End?" for 20 kopecks. The publishing house Tsentro-Sibiri printed cheap brochures and collections of works: "The Republic of Soviets", "Organization of People's Court" and "About the Earth". The price of the brochures was often lower than the price for an admission ticket to a club evening party, which gave an opportunity to the population with low-income to read them. It was an attempt to form such values of social culture as "justice" and "equality of opportunities" in the revolutionary time.

The Social Democratic Workers' Club "The 3rd International" was opened on February 24, 1918 on Voskresenskaya Street (Old Public Assembly) and held evening parties as well.

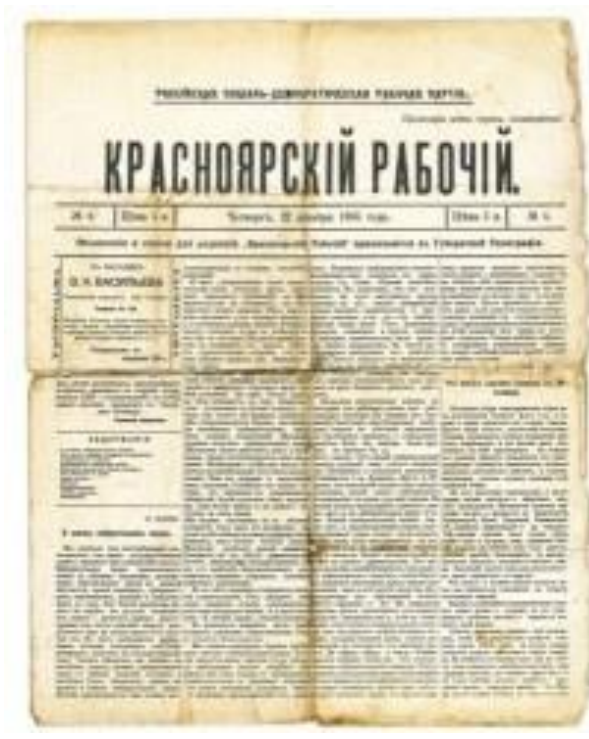

Fig. 3. Newspaper "Krasnoyarskii Rabochii"

250 people were at the opening, organized by the city committee of the Bolsheviks. There were different representatives among them: Ya. Dubrovinsky from the City Duma, Penazh from the Polish section, Leiman from the Latvian one, A. Shneider from the editorial office of the "Krasnoyarskii Rabochii", Vekshin from the Tomsk military post, A. Lebedeva from the Left Socialist-Revolutionaries and others. During the official part of the evening, the POWs orchestra performed, pianist and violinist Parkel played, The Internationale was sang. During important political events of the city the musical part had not only cognitive and entertaining functions, but ideological as well.

Up to 300 people gathered at different club city evenings. One-act play by A. Chekhov "On the High Road", a joke in one act by A. Chekhov "Willy-Nilly Tragedian" and a concert were performed for them. The choir of the Latvian section often performed with national Latvian dances. The fee for club members and students was 1 ruble, for guests -1 ruble 25 kopecks. Sometimes the price of a ticket for literary and musical evenings for guests reached 25 rubles. The main task of the club evenings was to 
create an atmosphere of a working family with proletarian class ideas.

On 15 October 1917, a thematic evening of working art was held to support the election campaign. Writer A.A. Bogdanov, actor Novoseltsev, political figures A. Pomerantseva, A. Shneider and the choir of workers performed there. The money for entry (50 kopecks per ticket) went to support the election campaign. Cultural and ideological evenings were the ordinary financial source for carrying out political events.

On 6 April 1918 the city theater performed a play for the printing business ("typographical") workers. The income from the sale of tickets, flowers, confetti and lottery was 2195 rubles 61 kopecks; the expenditure was 1174 rubles 96 kopecks. 500 rubles from them were paid to the actors and 112 to musicians. The play "Revolutionary Wedding", tickets for which could be bought in the National Printing House on Soviet Republic Street was also staged there. Slogan "Art without chains, beauty without bonds" determined the content of the most of Krasnoyarsk performances.

In October 1917, the Youth House was opened in Krasnoyarsk. In honor of this, a concert of violinist A.K. Melish took place in the city theater. The income received from selling tickets was allocated for the Youth House. The football ground of the club "Iunoshestvo" was opened. Krasnoyarsk authorities cared for the younger generation. Not all the evenings, from the point of view of the Krasnoyarsk authorities, were held at the high ideological level. On 10 April 1918 a concert-cabaret of the prisoners of war was held in favor of their organization of socialists - revolutionaries. The reviews in the Krasnoyarskii Rabochii were the following: "of vulgar nature, the organizers followed "a beaten dirty track leading away from art", "that's what the bourgeoisie leads us to if it rules the world for a long time" (Krasnoyarskii rabochii,
1918, 14 aprelia). The discontent was caused by the insufficiently high ideological level of the concert-cabaret of the prisoners of war. The concert-cabaret was a field of not only aesthetic, but also ideological struggle.

The economic activities of the authorities and society were given an important role in Krasnoyarsk. Repair works of the brick making factory at Bugach, which formerly belonged to Miakotin were taking place. Preparatory works on the construction of a machine-building plant in Starobazarnaia Square, where agricultural machinery, which was very necessary for peaceful life, should have been produced, were completed. Here, the city authorities' representation of the city as a socialist-organized settlement in production was manifested.

There were also workshops and household institutions for serving the population in Krasnoyarsk. In June 1918 there were a lot of them: 24 forge shops for forging and repairing carriages where only one-fourth was well equipped; 24 badly equipped woodworking shops, 6 conscientiously working tailor shops, 81 shoe-repair shops, only 5 of which corresponded to consumer demand; 8 potteries, 10 clock- and watchmakers, 9 bakeries, sausage making and coffee shops, 8 stocking making shops (only one was well equipped) and 9 laundry rooms without machines. One of them traditionally continued to serve the high income layer of the city society (repaired gold and silver watches). Without these workshops the normal daily life of the population would be impossible, but, unfortunately, in times of war a significant part of them did not have the necessary technical equipment.

Good equipment was in the shops organized by the former big owners. P.I. Gadalov (Fig. 4) requested permission to organize a weaving workshop on Bolshaya Street in Shneider's house No. 6, where there were: 4 hand looms, 1 reel, 1 large warper, 2 spools and a kalenender-press. 


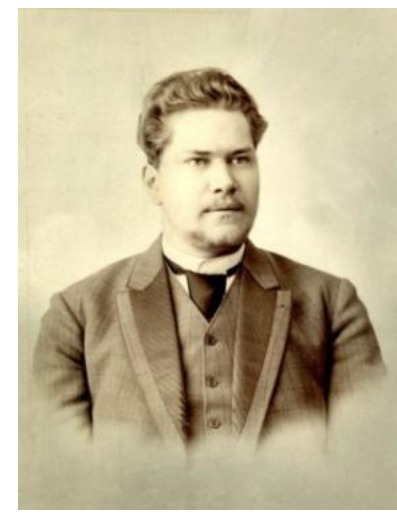

Fig. 4. P.I. Gadalov

The workshop was to produce shirts, tarpaulin and tick, necessary for the needs of the population and production. Unjust distribution of material wealth gave rise to the feeling of envy for well-off people, and after their property nationalization the interest in the follow-up activity and publication of information about them in the Krasnoyarskii Rabochii increased.

Until 2 March 1918 there were different societies in the Krasnoyarsk Shipping Company. It included the Joint-Stock Shipping Company, Urgent State Shipping Company, the Balagunnyes Shipping Company, Joint-Stock Company of the Yenisei Shipping Company, Kucherenkov and Cherepanov's Shipping Company. After nationalization the Yenisei National Shipping Company was established. Krasnoyarsk owners were worried about what they had earlier. Kucherenkov asked why his former steamer Yenisei was not repaired. This suggests that the new government either did not have the funds to repair, or it was not very economic, or both.

The economy could not exist not only without water transport, but railway one as well. To fight stowaways, fraud and speculation in Krasnoyarsk on 2 March 1918 flying squads were created. Tiasto was the squad commander. During March 90 pieces of textiles, 102 tile tea and 30.5 pounds of pekoe, 65 bars of toilet soap, 12 poods of soap, 7 poods of butter, 112 rake combs and combs, 4.5 dozen of stockings and socks, 1.5 dozen of gloves, 13 dozen of sewing threads, 80 packs of 20 pieces of cigarettes, 75 pairs of men's shoes and 29 pounds of fruit drops were requisitioned. According to the organizers' assumptions their revenues could reach up to 200,000 rubles. Such a value of social culture as "justice" is often associated with the order in the state or at least on a city scale. But, unfortunately, the order was violated by the events of the civil war. Since June 1918, because of the riot of the Czechoslovak corps, passenger trains were not running in Krasnoyarsk.

The Provincial Food Congress and the Krasnoyarsk Food Council solved the problems of food supplies. In connection with the fasting, the Food Council supplied more fresh fish on sale. It was sold at affordable prices. The fish was sold without cards and not in accordance with the norm. But there were other problems in food supply. There were difficulties with meat procurement. In addition, in Krasnoyarsk speculators were engaged in illegal sale of sugar, for which a fine of 25 to 50 rubles was levied. The difficulties of wartime did not allow providing food to the entire population of Krasnoyarsk at the proper level.

In May 1918, the Mongolian expedition was opened in Krasnoyarsk with the purpose of carrying out commodity exchange and meat procurement. Industrial goods were mainly produced for the exchange of agricultural products. These were 714 liters of kerosene, 2902 poods of horseshoe nails, 505 poods of strip iron and 11 long cars; 249 poods of embroidery paper, 681 poods of threads on reels and 372 poods of paper cotton, 3187 poods of white coarse calico, 2467 poods of cotton fabric and 1123 poods of felt; 450 poods of woolen footcloths and 1 car of galoshes. But food was also used: 950 cars of Scottish herring and 4 cars of tile tea. The variety of goods for exchange for meat was quite large. 
Representatives of the Krasnoyarsk Food Council understood that under conditions of the military and revolutionary times it was necessary to feed the population.

The Krasnoyarsk Food Council was also engaged in the distribution of other goods. A family of one or two people was provided with 4 arshins of cotton goods, a family of three to five people -6 arshins, a family of six to eight people -8 arshins, a family of nine and more people - more than 10 arshins and up to fifteen vershoks of width. Cloth goods were distributed not more than 4.5 arshins per capita. The values of the moral and social culture "family" and "justice" were the basis for the food distribution in Krasnoyarsk.

The City Duma discussed the mandatory decision of the Food Council on the procedure for opening kvass pubs, canteens and taverns. Drunkenness, which was called a threat to the gains of the revolution, to well-being, the customs of the city and the countryside gave rise to concerns. In the opinion of the City Duma, it created favorable conditions for Black-Hundred agitation. It was decided to use expeditions to destroy the moonshine stills, which were previously used by the Krasnoyarsk Executive Committee of Soldiers', Workers' and Peasants' Deputies (six of them were confiscated in one of the villages of the Sukhobuzimskaya Volost). In addition, it was proposed to create commissions for the distribution of loans to combat drunkenness, which in the conditions of revolutionary time acquired political character.

The city government directed logging for the city residents in the Kaltat district at the former state dacha. 1,700 running fathoms were logged, but despite the protection, the peasants of Bazaikha village started taking firewood out for their needs. Therefore, the City Council asked Zemsky department of the Executive Committee of the Council of Peasants' Deputies for help.
The Regional Congress of Food Bodies of Western Siberia was held on 11-22 April 1918. In accordance with its decisions, the Delegates' Congress of Food decided to provide assistance to the starving people. A pood of rye flour beyond the Urals cost 150-200 rubles. The ration rate was 30 pounds, 10 pounds of which were decided to be sent to the starving people. This decision was based on such a value of spiritual culture as "conscience".

Assistance was rendered to the disabled veterans of World War I. In January 1918 in Krasnoyarsk, the Union of "War-Maimed" Soldiers (UWMS) was established and on 30 April, "Brotherhood Day" was held. The second car shop of the Krasnoyarsk main railway shops (Fig. 5), feasible contributions in the sum of 21 rubles 20 kopecks were made for the disabled veterans of the First World War. In Orthodoxy, the idea of the unity of human nature is one of the fundamental concepts. St. John of Kronstadt said: "Love your neighbor as yourself, because loving your neighbor you love yourself, and hating your neighbor you, in the first instance, do harm to yourself, hating, first of all, your soul".

Unemployment was a big problem for the Krasnoyarsk authorities. On 31 May 1918, 2352 men and 938 women were registered at the labor exchange. 611 men and 104 women of them lived in Krasnoyarsk for less than three months. There were a lot of unskilled laborers, office clerks and metalworking industry workers among them,

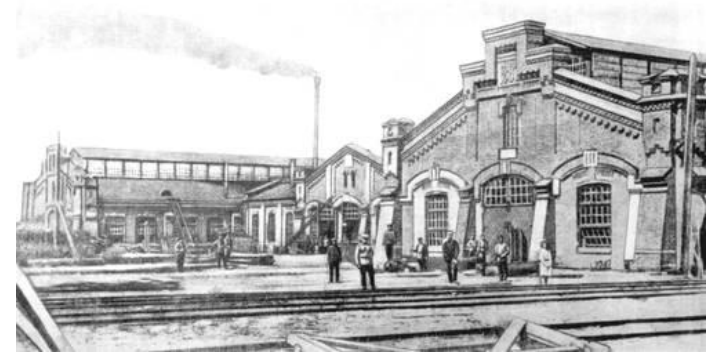

Fig. 5. Railway work shops in Krasnoyarsk 
$40 \%$ were unemployed teachers. 1064 people are assigned to work. With the help of labor material benefits can be gained and universal human values implemented. It has always had the highest moral value in the public consciousness.

The problem of the unemployed required its solution throughout the country. The unemployment range was from one hundred thousand in Moscow and about ten thousand in the Central Black Earth region. In Siberia and the Far East it was considered to be not higher than a "peaceful" time rate. The composition of the unemployed included: demobilized men, who were not connected with industry before the war; employees of liquidated organizations and institutions that served the war; former officers and population, dismissed for political reasons. The ideological component influenced an increase in the number of the unemployed due to former officers and politically insecure people.

Krasnoyarsk unemployed could go to the turf developments of the Far East, which "absorbed" 200-250 thousand Russian workers and 400-450 thousand Chinese ones. Laborers got from 4 rubles 50 kopecks to 5 rubles, which was lower than Moscow wages by sixty to seventy percent. The subsistence minimum per day in the Amur region was 2 rubles 80 kopecks, a pound of meat cost 38 kopecks, chum salmon 20 kopecks and a Chinese leather working suit was 60 rubles. Thus, the Krasnoyarsk unemployed could not have a very high standard of living when moving to the Far East.

An important direction of the Krasnoyarsk authorities's activity was education. The main type of school in Russia and in Krasnoyarsk in the early $20^{\text {th }}$ century was Primary School. In addition, there were schools of various departments. In 1918, a free exhibition of students' works was held at the railway school. The Krasnoyarsk department of public education introduced summer non-formal education in the districts. It was supposed to involve the majority of rural teachers with the condition of advanced training. The teachers' salary was 175 rubles.

The internationalists tried to make their contribution to the development of school. The "Krasnoyarskii Rabochii" published vivid appeals of the initiative group of the internationalist teachers: "Soviet Russia is the fortress of the proletariat, a torch calling on all the working people to rebel against the greatest robbers who are destroying and preparing to destroy all of humanity". They set the task of establishing a new socialist school.

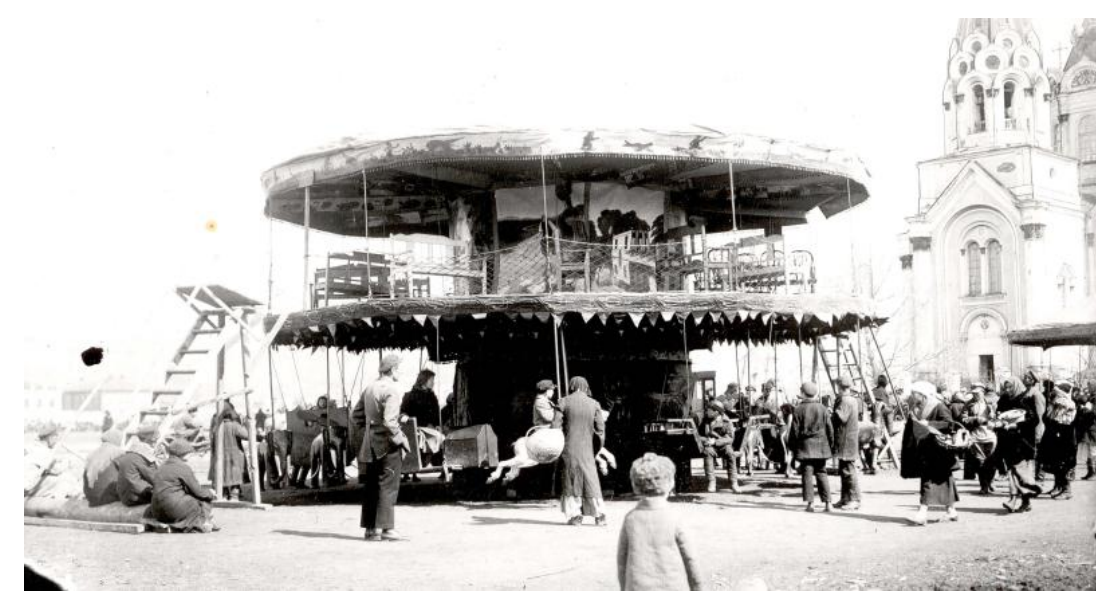

Fig. 6. Merry-go-round near the Cathedral of the Nativity of the Blessed Virgin Mary 
Kindergartens were involved into preparation for school. One of them admitted children from 4 to 7 years old with a monthly payment of $5 \%$ from their parents' salary, for two children the payment was $4 \%$. It included hot breakfast and classes from 9 am to $2 \mathrm{pm}$. Enrolment to the kindergarten was carried out in the premises on Vsekhsviatskaya Street in Vasiliev's house and in Novobazarmaya square, where the cultural and educational commission was located. They tried to charge payment for attending kindergarten by children "in all fairness".

The Solidarity Society opened a children's playground for 400 children with the aim of teaching them to work and discipline, and also to neutralize the negative influence of the street. The task to open a "Child Care Center" - a kindergarten for the children of democracy was set. Day nurseries were opened to release the parents for the summer agricultural work in the uyezds. Schoolchildren and children of preschool age - the future of the city were the object of regard for the Krasnoyarsk authorities during the military and revolutionary periods.

Attention was also paid to the artistically talented youth. For them, the Krasnoyarskii Rabochii published detailed information about the first Siberian People's Art Academy named after the Workers' and Peasants' Revolution. It was opened in the spring of 1918 in Tomsk. There were three departments in the Art Academy (painting, sculpture and architecture) and a sub-division of painting and graphics. Duration of training was from 3.5 to 5 years. Mandatory conditions for the admission were: age of 17 and secondary education. The tuition fee was 200 rubles per year. The Workers' and Peasants' Council of Siberia, which sent "petitions" for its scholarship holders, could exempt a student from the payment. The accompanying documents were: application letter with the indication of the desired department, certificates of education and qualifications and creative works that were provided separately. The artists were in demand for propaganda work during the revolutionary period.

Within the Siberian People's Art Academy named after the Workers' and Peasants' Revolution, by the resolution of the plenum of the Tomsk Provincial Executive Committee of the RCP dated 16 April 1918, a picture gallery, for which the mansion of the merchant of the First Guild I.I. Smirnov (Fig. 7, 8) had been confiscated, was created. Almost at the same time in April 1918, the Tomsk Art Library at the picture gallery was established by the decree of the Tomsk Provincial Executive Committee "On the Establishment of the Art Library at the Picture Gallery" (Tomskaia khudozhestvennaia biblioteka pri kartinnoi galeree). Thus, good conditions were created for the study of future Krasnoyarsk artists in Tomsk.

Educational work targeted different groups of the population. On 1 October 1917 "The Group for Organizational and Educational Activity among Female Workers" was created. The secretary of the group was E. Rumba. A literacy school was opened within the trade union of "Female Workers". It was also decided to open courses for soldiers, soldiers' wives and workers. They had to be held three times a week

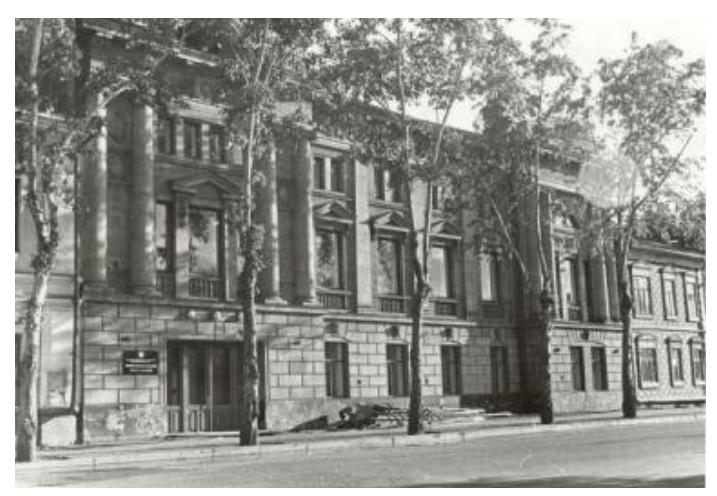

Fig. 7. House of the merchant of the First Guild I.I. Smirnov 


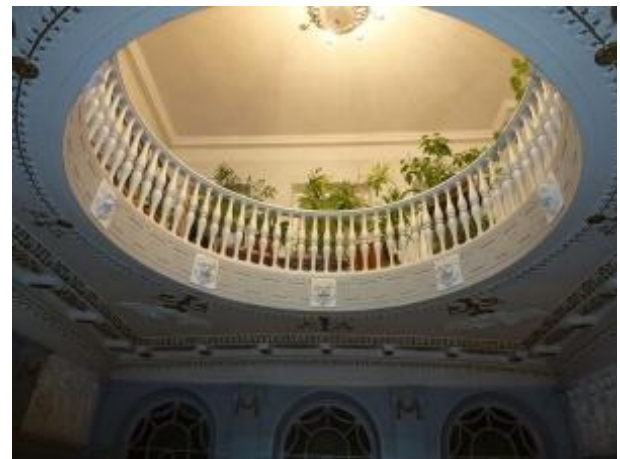

Fig. 8. Interior view of the house the merchant of the First Guild I.I. Smirnov

at the Workers' Club. The Russian language, arithmetic, geography, history, natural science, cooperation and political life were among the studied subjects. Despite the general educational nature, the courses were politically oriented.

The Krasnoyarsk authorities tried to take care of the health of the city residents. To provide summer holiday in the country, motor boat "Kormilets" cruised on the Yenisei River. A one way ticket cost 10-15 rubles. In April 1918, a project of the ambulance organization for the sick people was adopted in the city, for which seventeen thousand rubles were allocated. A doctor on duty should have worked at the patients' reception center from $8 \mathrm{pm}$ to $9 \mathrm{am}$. People were obliged to give voluntary contributions to the doctor on duty under the receipt of the City Council. Citizens could buy medicine in pharmacies from 9 am to 9 pm. Pharmacies on duty worked at night.

In middle of 1918, Krasnoyarsk was in the epicenter of the Civil War. The Czechoslovak military legion raised a revolt during its move from Ukraine to Vladivostok. As a result, on 19 June 1918, Soviet power in the city fell to the onslaught of A.V. Kolchak's armyof and in two days the members of the executive committee were arrested (Fig. 9). The Bolsheviks went underground.

The history of Krasnoyarsk in 1917-1918 allows refuting some accusations of ideological

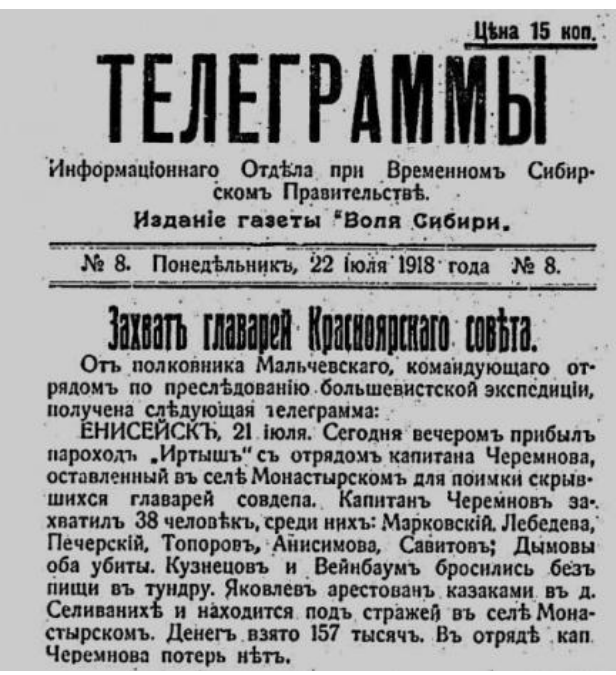

Fig. 9. Telegram about the Krasnoyarsk Council leaders' arrest

opponents. Despite the military and revolutionary time, the value of "justice", which is an immanent feature of human nature, was formed in the city. Orthodox traditions were taken into account, although the party ideology with the class approach to elections, the punishments of the Revolutionary Tribunal, the education system, etc. was replacing it. Much attention in wartime was paid to such moral values as "loyalty", "allegiance", "reliability", "commitment" and "responsibility", but there were also by-products of democratic euphoria in the army. The higher values (truth, good and beauty, faith, hope and love) are timeless, not utilitarian and unite people. The lower values in the hierarchy of values are transient; they change and are an object of struggle.

Even in military and revolutionary times the Krasnoyarsk authorities did not form a "catastrophic consciousness", the initial stage of which appeared when the sense of fear becomes a constant characteristic of consciousness. Its development was hampered by long-term optimistic revolutionary plans and formation of an active life philosophy of the city residents with the help of ideological work. 


\title{
References
}

Krasnoiarskii rabochii [The Krasnoyarskii Rabochii] (1918). 29 maia [May, 29].

Krasnoiarskii rabochii [The Krasnoyarskii Rabochii] (1918). 14 aprelia [April, 14].

Romanova, E.A. (2014). Eniseiskaia guberniia v gody Pervoi mirovoi voiny [The Yenisei Province in the Years of the First World War], In Rol' nauki v razvitii obshchestva: Sbornikstatei Mezhdunarodnoi nauchno-prakticheskoi konferentsii [The Role of Science in the Society Development: International Scientific Conference Proceedings], Ufa, 2, 114-122.

Romanova, E.A. (2014). Regiony Rossii v period Pervoi mirovoi voiny: Eniseiskaia guberniia i Krasnoiarsk [Regions of Russia in the Period of the First World War: the Yenisei Province and Krasnoyarsk], In Materialy III Mezhdunarodnoi nauchno-prakticheskoi konferentsii "Nauka v sovremennom informatsionnom obshchestve" [Proceedings of the Third Scientific Conference "Science in the Modern Information Society"]. North Charleston, USA, 2, 26-30.

Tsareva, E.S. (2014). Muzykal'naia zhizn' Krasnoiarska ot istokov do 1922 goda: puti formirovaniia muzykal'noi kul'tury evropeiskogo tipa [Music Life of Krasnoyarsk From the Origin till 1922: Ways of Forming Music Culture of European Model]. Krasnoyarsk, 368 p.

Tomskaia khudozhestvennaia biblioteka pri kartinnoi galeree [Tomsk Art Library within the Picture-Gallery]. Electronic Source. Available at: http://kraeved.lib.tomsk.ru/page/65/ (Accessed 7 September 2015).

Fotografii [Pictures]. Electronic Source. Available at: http://fotoyarsk.ru/photo/goroda-kraya/ krasnoyarsk.html (Accessed 7 September 2015)

Zapesotskii, A.S. (2015). Epokha informatsionnykh voin i problemy obespecheniia dukhovnoi bezopasnosti obshchestva [The Epoch of Information Wars and the Problems of Spiritual Security of Society], In Voprosy kul'turologii [The Culturology Issues], (4), 6-12.

\section{Красноярск в 1917 - середине 1918 гг. глазами газеты «Красноярский рабочий»}

\author{
Е.А. Романова \\ Красноярский государственныий институт искусств \\ Россия, 660049, Красноярск, ул. Ленина, 22
}

В данной статье исследуется жизнь Красноярска в период завершения Первой мировой войны, начала Гражданской войны и революиионных событий 1917 г. Рассматривается политическая, сочиально-экономическая и культурная работа на фоне современных информационных войн и культурных иенностей.

Ключевые слова: информачионные войны, культурные ценности, Первая мировая война, Гражданская война, решение политических, сочиально-экономических и культурных проблем в Красноярске.

Научная специальность: 07.00.00 - исторические науки и археология, 10.00.00-филологические науки. 